\title{
IS BITCOIN AN OPPORTUNITY OR A THREAT TO THE RELEVANCE OF ACCOUNTING INFORMATION?
}

\section{SERIA A BITCOIN UMA OPORTUNIDADE OU UMA AMEAÇA Å RELEVÂNCIA DA INFORMAÇÃO CONTÁBIL?}

0 artigo foi aprovado e apresentado no $45^{\circ}$ World Continuous Auditing \& Reporting Symposium (WCARS), realizado em 05 de junho de 2019, em Florianópolis (SC)

\begin{abstract}
Positive accounting research is the one that addresses the informational perspective of accounting (Watts \& Zimmerman, 1990). In this scenario, studies on the relevance of accounting information in the capital market stands out. Some of these surveys consider the effects of firms' extrinsic variables on the ability of accounting information to predict stock prices. Considering the apparent inverse relationship between Bitcoin and the capital markets, being this cryptocurrency able to be used as hedge for investors in these markets (Bouri et al., 2017), the purpose of this study was to analyze the influence of the Bitcoin price in the market value of the companies listed on the $[B]^{3}$ in conjunction with the accounting information. Panel data regressions were performed considering the stock price and return as dependent variables and Net Income, Equity and Bitcoin quotation as regressors. From 356 observations concerning 89 different companies, it was possible to verify, with a 95\% confidence level, that the companies' market value is negatively influenced by Bitcoin's price increase. This suggests a preference for investments in the cryptocurrency market over the capital market when the first one is on the rise, corroborating Bouri et al. (2017). In addition, Equity loses significance and Net Income is reduced when Bitcoin is included in the model, indicating a potential risk to accounting information in terms of relevance. The research has limitations regarding the use of a single cryptocurrency in the face of several existing ones and also in the selection of only one exercise as sample cut.
\end{abstract}

Keywords: Blockchain; Bitcoin; Value Relevance; Stock Market.

\section{RESUMO}

A pesquisa contábil positivista é aquela que aborda a perspectiva informacional da contabilidade (Watts \& Zimmerman, 1990). Nesse cenário, destacam-se os estudos de relevância da informação contábil no mercado de capitais. Algumas destas pesquisas consideram os efeitos de variáveis extrínsecas às empresas na capacidade das informações contábeis predizerem preços de ações. Considerando a aparente relação inversa entre a Bitcoin e os mercados de capitais, sendo esta criptomoeda capaz, inclusive, de servir como hedge por investidores destes mercados (Bouri et al., 2017), o objetivo deste estudo foi analisar a influência do preço das ações da Bitcoin no valor de mercado das empresas listadas na [B] $]^{3} \mathrm{em}$ conjunto com as informações contábeis. Foram realizadas regressões com dados em painel considerando o preço e o retorno das ações como variáveis dependentes e o lucro líquido, o patrimônio líquido e a cotação do Bitcoin como regressores. Diante de 356 observações referentes a 89 diferentes empresas, foi possível verificar, com um nível de confiança de $95 \%$, que o valor de mercado das empresas sofre uma influência negativa diante do aumento do preço da Bitcoin. Isso sugere uma preferência de investimentos no mercado de criptomoedas em detrimento ao mercado de capitais quando o primeiro está em ascensão, corroborando Bouri et al. (2017). Ademais, o patrimônio líquido perde sua significância e o lucro líquido têm seu coeficiente reduzido quando a Bitcoin é inclusa no modelo, indicando um risco potencial para a informação contábil em termos de relevância. A pesquisa apresenta limitações quanto ao uso de uma única criptomoeda perante as diversas existentes e também diante da seleção de apenas um exercício como recorte amostral.

Palavras-Chave: Blockchain; Bitcoin; Value Relevance; Mercado de Capitais.

\section{Ronan Reis Marcal}

Doutorando em Contabilidade pela

Universidade Federal de Santa Catarina (UFSC). Mestre em Ciências Contábeis pela Universidade Federal do Rio de Janeiro (UFRJ). Graduado em Ciências Contábeis pelo Centro Universitário Carioca (UNICARIOCA). Contato: Rua Eng. Agronômico Andrei Cristian Ferreira s/n - Trindade, Florianópolis - SC, 88040900. E-mail:m.ronanreis@gmail.com

\section{Bruno Chacon Prata}

Mestrando em Contabilidade pela Universidade Federal de Santa Catarina (UFSC). Graduado em Ciências Contábeis pela Universidade Estadual de Londrina (UEL). Contato: Rua Eng. Agronômico Andrei Cristian Ferreira, $s / n$ - Trindade, Florianópolis - SC, 88040-900. E-mail: brunno_chacon@hotmail.com

\section{Leonardo Flach}

Pós-doutor em Contabilidade e Finanças pelo Massachusetts Institute of Technology (MIT/EUA). Professor do Programa de Pós-graduação em Contabilidade (PPGC) e do Programa de Pós-Graduação em Gestão Universitária (UFSC). Coordenador do Programa de Pós-Graduação em Gestão Universitária. Doutor em Administração (UFRGS), com doutorado sanduíche na Freie Universität Berlin (Alemanha). Contato: Rua Eng. Agronômico Andre Cristian Ferreira, $\mathrm{s} / \mathrm{n}$ - Trindade, Florianópolis - SC, 88040-900. E-mail: leonardo.flach@gmail.com 


\section{INTRODUCTION}

Considering the Conceptual Framework for Financial Reporting Pronouncement (2010) by the International Accounting Standard Board (IASB), the primary objective of accounting science is to provide useful information about the entities. In order to fulfill this objective, there is a need for two characteristics that are fundamental to the accounting information: relevance and faithful representation.

About relevance, Alves, Silva, Marques and Macedo (2011) point out that this feature has been widely explored in the academic scope at researches about value relevance. According Fonseca, Marques and Santos (2018), several researchers seek to identify a relationship between financial information and the market value of companies, and this topic is being treated as relevant because accounting information has powerful explanatory characteristics.

According to Watts and Zimmerman (1990), it was in the 1960s, through empirical research on the usefulness of financial accounting content, such as Ball and Brown (1968) and Beaver (1968), that modern positivist accounting research has developed, thus reinforcing the so-called "information perspective" of accounting data against the stock price.

It is also noteworthy that Positive Accounting Theory is related with the Efficient Market Hypothesis (EMH), pointed by Fama (1970), which suggests a reflection on the stock price according to the information available on the observed entity.

The EMH, in turn, could take three forms, namely, weak, semi-strong and strong, denoting the speed of information absorption. Studies such as Sarlo Neto et al. (2005) and Marçal, Batista and Macedo (2018) suggest the semi-strong form as the most significant in terms of accounting information efficiency. The recent study of Batista, Maia and Romero (2018) suggests the presence of semi-strong efficiency for the stock market in Brazil.

Since the seminal studies of value relevance (Beaver, 1968, Ball \& Brown, 1968), several models were tested to elucidate the relevance of one or other information. However, for Alves et al. (2011), the model of Ohlson (1995) - which considers profits as benchmarks for market valuation rather than dividends, and which measures as an abnormal result the product of lagged equity and the risk-free interest rate (Lopes, 2001) - is one of the most widely applied. Still according to Alves et al. (2011), it was in front of the model proposed by Collins, Maydew and Weiss (1997) that the variables "Earnings" and "Book Value" became reference in researches of this core. It occurs that the model of Collins et al. (1997) simplifies the classic model of Ohlson (1995), using only accounting data.

Although some financial variables are often used in theoretical models of value relevance, some research sought to add non-accounting variables, intrinsic or extrinsic to the company, in order to identify the reaction of accounting information before such an inclusion. Examples are the research from Chamisa, Mangena, Pamburai and Tauringana (2018), Sutopo, Kot, Adiati and Ardila (2018) and Tshipa, Brummer and Du Toit (2018). They added respectively inflationary effects of social liability factors and factors relating to the corporate governance to the Ohlson model (1995).

Given the present theme of the cryptocurrency market, it is necessary to highlight the influence of these assets (virtual currencies) in the traditional capital markets. This can be sustained at the idea that the cryptocurrency market is a potential competitor to the capital market (Dyhrberg, 2015), especially considering the presence of more than one million investors in digital currencies in Brazil against only 613,000 investors in the Brasil, Bolsa, Balcão [B] ${ }^{3}$ (Costal \& Meira, 2017). It should be noted that on a wide range of cryptocurrency, the Bitcoin have emphasis derived from its pioneering spirit and its volume (Gandal \& Oberman, 2018).

Considering the timeliness and relevance of the topic, this study aims to analyze the influence of the Bitcoin price in the market value of the companies listed on the $[\mathrm{B}]^{3}$ in conjunction with the accounting information. For this purpose, we adopted as control variables, both variables proposed by Collins et al. (1997) and we added the price of Bitcoin as a stimulus variable. Following the traditional research of value relevance, we adopted as response variables the stock price and stock returns.

The findings of this study contribute in two ways: (1) to the academics, the results have precursors that aggregate consolidated variables in the scientific studies of value relevance, observing the influence of the main cryptocurrency traded in Brazil and in the world. In this sense, it is possible to have earnings comparisons or marginal loss of predictive power of accounting information before the market; (2) to society, these results can demonstrate that investors can have the effects derived from an external asset to $[\mathrm{B}]^{3}$, arranged in the quotation of assets that can compose their market portfolios, highlighting potential risks as well or even potential improvement scenarios.

\section{LITERATURE REVIEW}

\subsection{Positive Accounting Theory and Value Relevance}

Positive Accounting Theory states that the financial reporting has two aspects: market signaling and monitoring of managerial behavior (Watts and Zimmerman, 1978). In order to understand the Positive Accounting Theory, it is necessary to have an understanding of the difference between the Positive and Normative Theory. While the goal of Normative Accounting Theory is to determine how accounting it should work, Positive Accounting Theory aims to explain and predict the accounting practice (Queiroz \& Almeida, 2017).

The Positive Accounting Theory appeared especially because of the first studies that have not sought to study accounting practices but wanted to explain and predict them. The pioneering studies in accounting with a positivist greatest impact were the studies from Ball and Brown (1968) and Beaver (1968), who conducted empirical studies in the accounting literature. 
Another factor that helped in the development of Positive Accounting Theory was the ongoing debate on the regulation by the government accounting disclosure, which stimulated the emergence of empirical studies that asked if there was any interest in the regulations. So, researchers resorted to the interests of managers and company accountants, besides the politicians and bureaucrats who worked to increase the welfare and finance through the effect of regulation of accounting practices (Watts \& Zimmerman, 1978).

Thus, Watts \& Zimmerman (1978) developed the assumptions of Positive Theory, which are: (a) Hypothesis of Incentive Plans, which says that companies with more aggressive compensation plans tend to handle more their statements; (b) Assumption of the degree of indebtedness, which reports on the manipulation of accounting data before the debts of breaches of contract costs; and (c) the hypothesis of the political costs or size, which seeks to establish a relationship between the size of companies and the accounting methods used for the design of the accounting information quality.

National and international studies have tried to test these hypotheses (Hagerman \& Zmijewski, 1979; Healy, 1985; Skinner \& Dichev, 2002; Bergstresser \& Philippon, 2005), showing the importance of this line of research.

Following the line of Positive Accounting Theory, the value relevance can also be cited as an indicator of the financial statements. The value relevance perspective aims to study and understanding of the importance that the carrying amount may have. Research on the value relevance try to find a relationship between the market values of companies and the disclosure of financial statements. (Barth, Beaver \& Landsman, 2001; Verrecchia, 2001)

Studies about the relevance of accounting information used various valuation models for the structure of tests and typically use the market value of equity as a reference for how to analyze the book values represent informational content for investors, i.e. if the accounting information show significant association with stock prices, it should be considered a relevant information (Barth et al 2001; Song, Thomas \& Yi, 2010).

It should be noted that, according to Barth et al. (2001), the main model used in research of value relevance is the model of Ohlson (1995), which considers the market value as a linear function of the amount recorded for accounting (equity) and the abnormal profits. This model was simplified by Collins et al. (1997), according to Alves et al. (2011), making reference in this area and, as a consequence, their independent variables (earnings and book value) became control variables in the stock price given its wide use and validation in previous research.

\subsection{Efficient Market Hypothesis (EMH)}

Initially proposed by Fama (1970), the Efficient Market Hypothesis (EMH) considers an efficient market if stock prices, at any time, fully reflect the relevant and available information, i.e. there should be no disagreement between an asset value and its true value. Thus, the values reflect all the assets related information, as it presupposes the absence of transaction costs and the availability of all the information for all users of the market (Magalhães-Timotio, Leite Filho \& Eça, 2017; Boya, 2019)

Fama (1970) proposed three forms of market efficiency according to the speed that the market absorbs information: weak, semi-strong and strong. Table 1 briefly explains each of these forms.

Table 1 - Market Efficiency Forms

\begin{tabular}{l|l}
\hline Form & Market Absorption \\
\hline Weak & $\begin{array}{l}\text { Asset prices are formed on historical prices, making it impossible to obtain abnormal returns by } \\
\text { information from the past. } \\
\text { Asset prices reflect not only the historical values but also quickly absorb and reflect all infor- } \\
\text { mation disclosed. This being the most representative way for the research of value relevance. } \\
\text { Asset prices already reflect all information, even confidential. In this case, the disclosure of } \\
\text { financial statements would have little or no relevance given that prices were already reflecting } \\
\text { the changes of the period even though they had not been disclosed. }\end{array}$ \\
\hline
\end{tabular}

Source: Adapted from Marçal et al. (2018)

Sarlo Neto (2004) corroborates in his study that the form of semi-strong efficiency is the one most linked to accounting and, in this research, the author certifies that this form of efficiency to the capital market of Brazil. In addition, confirming the continuity of this trend to the present day, we have the appointment made by the recent study of Batista, Maia and Romero (2018).

\subsection{Bitcoin}

Virtual currencies are a relatively modern subject. To understand the concept of virtual currency, we need to differentiate them from virtual money. According to Grignon (2009), virtual money is just the idea that, because of technology, money can be considered a digital object. The virtual currency is as real currency, the difference is that the first one is not issued by national central banks (Albuquerque \& Callado, 2015). 
Discussions on virtual currencies have been placed on the agenda in the mid-80s, however, it was in 2009 that the Bitcoin first invested in the business (Gandal \& Oberman, 2018). The bitcoins using an encrypted system to generate the coins, which is performed by system users, not by a regulatory agency of the government centrally as normal currency (Albuquerque \& Callado, 2015). All information of the Bitcoin transactions to date are stored in a logbook called Blockchain in encrypted form (Costal \& Meira, 2017).

One cannot ignore the relevance of Bitcoin currently. In Brazil, more than one million individuals invest in cryptocurrency against 613,000 investors in $[\mathrm{B}]^{3}$ - so it is possible to understand the relevance of cryptocurrency, especially Bitcoin to the market as a whole (Costal \& Meira, 2017).

According to Gandal and Oberman (2018, p. 86), "the total value of all bitcoins in circulation today is about 28 billion dollars, and inspired dozens of competitors cryptocurrency follow a similar design." Thus, confirming the highlight that this new type of investment is causing in the market.

Even being a hot topic, studies on Bitcoins are taking a leading role in the academic field. Raiborn and Sivitanides (2014) studied the information on Bitcoin must be taken into account in the accounting information. They discussed important topics on Bitcoin and on six topics of financial accounting: classification of assets, mining activity, investment, trade, merger and acquisition and dissemination.

Corbet, Lucey and Yarovya (2017) examined the existence and the dates of price bubbles in Bitcoin and Ethereum cryptocurrency. They concluded that there are periods of light behavior of bubbles and claim that Bitcoin almost certainly experiencing a bubble phase currently.

Easley, O'Hara and Basu (2018) investigated the role that transaction fees play in the evolution of blockchain and bitcoin. As a result, the authors concluded that in the absence of transaction fees, the logo of the blockchain time is not feasible.

Henriques and Sadorsky (2018) investigated the implications of the gold substitution in an investment portfolio by Bitcoin. The study found that risk-averse investors would be willing to pay a high rate of performance to change a portfolio of gold to a portfolio with Bitcoin.

Yaya, Ephraim and Mudida (2019) sought to investigate market efficiency and the persistence of volatility in 12 cryptocurrencies during periods of pre-crash and post-crash. The authors found that Bitcoin markets and most altcoins (alternative cryptocurrency) considered in the samples can be dubbed efficient, and these are highly volatile, particularly in post-collision sample.

Perhaps the study with the closest objective to what is intended to be verified in this research was Dyhrberg (2015). When considering a sample of 1769 observations from the Financial Times Stock Exchange Index (FTSE) between 2010 and 2015 , this author indicates that Bitcoin serves as a hedge tool for investors, enabling them to mitigate specific market risk.

Later, Bouri, Gupta, Tiwari and Roubaud (2017) would replicate this research, now considering 14 different stock markets, including the Brazilian one. Considering that the hedging capacity found by Dyhrberg (2015) was equally verified in their work and that their sample consisted of distinct markets - some developed and some not - the authors conclude that Bitcoin can help investors to protect themselves from stock market uncertainties in general, especially when markets are down.

\section{METHOD}

As for the methodological procedures, this study is characterized as empirical-positivist making use of a quantitative approach given the data collection accompanied by a corresponding analysis. The study population with respect to publicly traded companies listed on the $[\mathrm{B}]^{3}$ in the year 2018 . The definition for this single year stems from the impact occurred at that time to the volatility and pricing of Bitcoin, which is the largest research interest variable (Laurent, 2018).

The price of Bitcoin was collected on the website www.investing.com, and the other variables were collected directly from the Economática ${ }^{\circledR}$ platform.

Data were collected at quarterly intervals to identify the behavior of variables during 2018 and it was possible to increase the amount of the sample given the multiplication of data from each company for 4 remarks.

Were used as dependent variables the Stock Price (SP) and the monthly Stock Return (SR), and this information is collected in a D + 5 date, i.e. a date five days after the publication of quarterly accounting statement in question. A measure of tolerance of up to two days for any dates that coincide with holidays or non-working days was adopted. All this treatment is in accordance with the semi-strong efficiency of the Brazilian market reported by Batista, Maia and Romero (2018).

We added Earnings Per Share (EPS) and Book Value Per Share (BVPS) as control variables to mitigate the risk of endogeneity of the default of relevant variables. These variables are derived from the seminal work of Ohlson (1995) and Collins et al. (1997) and are used in large-scale surveys that seek to predict the price and / or return of shares (Alves et al., 2011).

Finally, the stimulus variable tested in this research concerns the price of Bitcoin cryptocurrency (BTC), measured in Brazilian Reais, in each quarter closing period. While EPS and BVPS variables do not suffer scale differences when compared to the price of the shares to be equated by the total number of shares of each company, the variable BTC cannot be balanced by the total shares of the company because it is a character variable extrinsic, i.e. there is no direct relationship with each company observed. However, given the possible discrepancy scales, this variable was treated before its natural logarithm. 
Aiming to achieve the chronological tracking properly, the data were worked on a fully balanced panel. Because this, it was necessary to find what would be the best approach to be made on panel data, i.e., control of fixed effects, random effects or pooled data. To this end, were used Chow test, Lagrange Multiplier of Breusch-Pagan test (LM Breusch- Pagan) and Hausman test (Gujarati \& Porter, 2011).

Due to this treatment and also the lack of some data, it was eliminated a few observations. Table 2 shows the amount of deletions and their motives and reports the initial population and the resulting final sample contemplated in the search.

Table 2 - Population and Sample

\begin{tabular}{|c|c|c|c|}
\hline \multicolumn{4}{|c|}{ Panel A } \\
\hline Time / Exclusion & Amount & \multicolumn{2}{|l|}{ Deleted data } \\
\hline Step 1 - Population & 384 & \multicolumn{2}{|l|}{-} \\
\hline Step 2 - Exclusion for missing data & 376 & \multicolumn{2}{|l|}{ (8) } \\
\hline Step 3 - Exclusion for balancing the panel & 356 & \multicolumn{2}{|l|}{$(20)$} \\
\hline \multicolumn{4}{|c|}{ Panel B } \\
\hline Final sample & 356 observations & Total of Companies & 89 \\
\hline
\end{tabular}

As seen in Table 2, the final sample amounted to a total of 356 observations. As a balanced panel and a chronological delta of four units (four quarters), we had the presence of 89 different companies to be observed in this study. It is noteworthy that before the data collection, it was based the criteria of greater liquidity for companies that contained more than one action available. This is done in order to avoid the concentration of more than one result per company, which would be a potential risk of bias in the research.

Thus, the models presented to the survey were:

(1) $S P_{i, t}=\beta_{0}+\beta_{1} E P S_{i, t}+\beta_{2} B V P S_{i, t}+\beta_{3} B T C_{t}+\mu_{i, t}$

(2) $S R_{i, t}=\beta_{0}+\beta_{1}$ EPS $_{i, t}+\beta_{2}$ BVPS $_{i, t}+\beta_{3} B T C_{t}+\mu_{i, t}$

Where:

$\mathrm{SP}_{\mathrm{i}, \mathrm{t}}$ is the stock price of the company $\mathrm{i}$ in the period $\mathrm{t}$;

$\mathrm{SR}_{\mathrm{i}, \mathrm{t}}$ is the monthly stock return of company $\mathrm{i}$, in the period $\mathrm{t}$;

$\beta_{0}$ is the intercept of the regression;

$\beta_{1,2,3}$ are the angular coefficients of the regression;

$E P S_{\mathrm{i}, \mathrm{t}}$ is the net profit of the company $\mathrm{i}$ in the period $\mathrm{t}$, divided by their respective number of shares;

$B V P S_{i, t}$ is the book value of the company $i$ in the period $t$, divided by their respective number of shares;

$B T C_{\mathrm{t}}$ is the natural logarithm of the price of Bitcoin observed in the period $\mathrm{t}$;

$\mu_{i, t}$ is the error term of the regression.

Faced with the equations (1) and (2), we found the following research hypotheses:

$H_{1}$ : The growth of Bitcoin in terms of market price quotation, negatively affects the stock price of companies listed on the [B] $]^{3}$.

$H_{2}$ : The growth of Bitcoin in terms of market price quotation, negatively affects the stock returns of companies listed on [B] ${ }^{3}$.

Both hypotheses are supported by the apparent competition between the capital and the alternative market cryptocurrency (Costal \& Meira, 2017). The use of Bitcoin for speculative purposes, such as capital market assets, had been related by Hur, Jeon and Yoo (2015) and, besides this, a recent survey reported the presence of more than twice Bitcoin investors compared to traditional investors in the Brazilian capital market (Gomes \& Laporta, 2018).

Considering that the maximum value of Bitcoin price occurred in December 2017 (Hayes, 2019) and the previously mentioned research was done in the subsequent year in the Brazilian scenario, it is pertinent to assume that the Bitcoin market is parallel to the Brazilian capital market $[B]^{3}$ for their investors. This was pointed out by Dyhrberg (2015) in the UK market and Bouri et al. (2017) in 14 different markets. So, these surveys support the proposed idea that Bitcoin's rise tends to mitigate $[\mathrm{B}]^{3}$ 's asset prices.

Such assumptions identifying the influence of the main cryptocurrency Brazil in front of the capital market and denote the predictive ability of financial information, in the case, profit and equity, when accompanied by an extrinsic force market. 
All statistical tests and regressions were made considering always a confidence level of 95\% with STATA ${ }^{\circledR}$ software.

\section{RESULTS}

The first step made in this section refers to the descriptive summaries of research variables (see Table 3).

Table 3 - Descriptive statistics

\begin{tabular}{l|l|l|l|l|l}
\hline Variable & Mean & Median & Standard Deviation & Minimum & Maximum \\
\hline SP & 26.09 & 20.68 & 19.76 & 3.46 & 180.85 \\
SR & 3.70 & 2.90 & 10.74 & -39.06 & 45.24 \\
EPS & 0.88 & 0.67 & 1.73 & -9.59 & 11.42 \\
BVPS & 13.40 & 9.92 & 12.66 & -14.33 & 68.68 \\
BTC & 4.34 & 4.39 & 0.10 & 4.17 & 4.43 \\
\hline
\end{tabular}

It is possible to note on the results of Table 3 that, except for BTC variable, which has been treated on its natural logarithm, and EPS variable, the remaining data show great dispersion (standard deviation of up to 19 units). In addition, it is noted that for 4 out of the 5 research variables the average is higher than the median, suggesting thus a lengthening of the upper tail of the distribution.

To identify a possible problem in this respect and at the same, meet one of the basic conditions for the use of regressions estimated by Ordinary Least Squares (OLS), it was performed the Jarque-Bera test to verify the normality of the residuals. The result was a p-value $<0.000$ for both equations (1) and (2). So, it was refuted the null hypothesis of normality, however, given the size of the sample (356 observations) and according to the Central Limit Theorem, such assumption could be relaxed (Gujarati \& Porter, 2011).

Another basic requirement for continuity of the analysis relates to the dispersion of the error. To verify the homoscedasticity condition of the error, for both equations we applied the Breusch-Pagan test. In Equation (1) it was obtained a $p$-value $<0.000$ and for equation (2), the $p$-value was 0,0415 . Thus, given the significance level of $5 \%$ proposed for this study, both equations presented heteroskedastic error. For the correction of this problem, it was adopted White robust correction, indicated as suitable for such a function by Gujarati and Porter (2011).

Moreover, it was necessary to identify the degree of collinearity between the independent variables of the models. For this purpose, was checked Variance Inflation Factor (VIF) data. Following the rule of thumb arranged by Gujarati and Porter (2011) that VIF valuesless than 10 units do not denote severe collinearity issues, it was possible to continue the analysis since the average VIF obtained between the EPS, BVPS and BTC was only 1.34.

For purposes of disclosure in a more analytical way, Table 4 shows the correlation between all independent and dependent variables of the study.

Table 4 - Correlation Matrix

\begin{tabular}{l|l|l|l|l|l}
\hline- & SP & SR & EPS & BVPS & BTC \\
\hline SP & 1.0000 & - & - & - & - \\
SR & .0886 & & & - \\
EPS & $(.0949)$ & 1.0000 & - & - & - \\
& .4155 & .1874 & & & - \\
BVPS & $(.0000)$ & $(.0004)$ & 1.0000 & - & - \\
& .3618 & .0522 & .5368 & 1.0000 & 1.0000 \\
BTC & $(.0000)$ & $(.3258)$ & $(.0000)$ & -0.0004 & $(.9938)$ \\
\hline
\end{tabular}

With the acceptance of the prerequisites for the OLS regression analysis, in sequence, are presented the analysis of Equations (1) and (2). Firstly, the best approach of the panel data, as mentioned in the methodological procedures, is reported in the following Table. 
Table 5 - Panel approach

\begin{tabular}{l|l|l|l}
\hline Equation & Test & F / Chibar $\mathbf{~}^{\mathbf{~ / ~ C h i ~}} \mathbf{~}^{\mathbf{2}}$ & $\mathbf{p}$-value \\
\hline 1 & Chow & 36.08 & 0.0000 \\
1 & LM Breusch-Pagan & 402.83 & 0.0000 \\
1 & Hausman & 44.35 & 0.0000 \\
2 & Chow & 0.86 & 0.7992 \\
2 & LM Breusch-Pagan & 0.00 & 1.0000 \\
2 & Hausman & 2.43 & 0.4881 \\
\hline
\end{tabular}

As results of Table 5, it is possible to realize the best fit of the fixed effects approach to Equation (1). In addition, considering that the proposal this approach track of the data over time, we made additionally a serial autocorrelation test.

Then, we applied the Wooldridge test, supported by Drukker (2003). The result was a p-value of 0.0037, so the autocorrelation problem of the presence of the first order given the rejection of the null hypothesis was indicated. As a corrective measure we made a cluster analysis of standard errors (Hoechle, 2007). The results of the Equation (1), considering this adjustment, is presented in Table 6.

Table 6 - Results - Equation (1)

\begin{tabular}{|c|c|c|c|c|c|c|}
\hline \multicolumn{7}{|c|}{ Panel A } \\
\hline \multicolumn{2}{|l|}{ SP } & \multicolumn{2}{|l|}{ Coefficient } & $t$ & \multicolumn{2}{|l|}{ p-value } \\
\hline \multicolumn{2}{|l|}{ EPS } & \multicolumn{2}{|l|}{1.124325} & 2.70 & \multicolumn{2}{|l|}{$0.008^{\star * \star}$} \\
\hline \multicolumn{2}{|l|}{ BVPS } & \multicolumn{2}{|l|}{-0.1480826} & -0.95 & \multicolumn{2}{|l|}{0.344} \\
\hline \multicolumn{2}{|l|}{ BTC } & \multicolumn{2}{|l|}{-15.77706} & -5.09 & \multicolumn{2}{|l|}{$0.000^{\star \star \star}$} \\
\hline \multicolumn{2}{|l|}{ Intercept } & \multicolumn{2}{|l|}{95.63366} & 7.37 & \multicolumn{2}{|l|}{$0.000 * \star \star$} \\
\hline \multicolumn{7}{|c|}{ Panel B } \\
\hline $\mathbf{R}^{2}$ Overall & 0.0119 & & Number of $o$ & rvations & & 356 \\
\hline $\mathbf{R}^{2}$ Within & .1786 & & $\mathbf{R}^{2}$ Between & & & 0.0005 \\
\hline $\mathbf{F}$ & 1.55 & & p-value (F) & & & $0.0000 * * *$ \\
\hline
\end{tabular}

According to the results of Table 6, it is possible to verify the statistical significance of the model as a whole, considering the p-value $(F)<0000$. So, was not accepted the null hypothesis of no linear relationship of all variables together. In addition, explanatory power considering the control of fixed effects ( $\mathrm{R}^{2}$ Within) was about $18 \%$, thus suggesting that the model as a whole can explain this percentage varying the study of the response variable.

It is noticed that among the control variables, only EPS variable statistically significant ( $p$-value 0.008 ), being maintained the signal of previous research, i.e. the increase in this variable implies a positive variation of the stock price.

As a complement, the same regression was performed, but without the BTC variable. Done this procedure, the variable EPS remains positive and statistically significant, but it doesn't occur with BVPS variable. So, there is a suggestion of a lost relevance of Equity as a relevant factor when considering the price of Bitcoin together. This result seems to be important to diagnose a loss of accounting information efficiency on the inclusion of an external information.

Regarding the regressor BTC, the main variable, there is also a statistical significance respecting a confidence level of $99 \%$. Its coefficient indicates that the increase of one unit of this variable would imply a reduction of approximately 16 units in stock price.

This seems to agree with the argument that, while the price of Bitcoin rises, the price of the capital market stocks down, and this inverse relationship arising from a possible stampede of investors from $[\mathrm{B}]^{3}$ to the parallel market cryptocurrency (Costal \& Meira, 2017; Gomes \& Laporta, 2018).

That interpretation could also be applied in a related manner to what is stated by Henriques and Sadorsky (2018) by claiming that investors are likely to migrate from gold to Bitcoin, so it would be feasible to also change from the capital market for the Bitcoin, apparently. Given this result, is not plausible refute the $\mathrm{H} 1$ of this study.

Continuing the analysis, the same procedures adopted in Equation (1) were taken to Equation (2). Unlike what happened in Equation (1) approaches test, Equation (2) suggests the use of pooled data, so the results of this estimation are reported in Table 7. 
Table 7 - Results - Equation (2)

\begin{tabular}{|c|c|c|c|c|}
\hline \multicolumn{5}{|c|}{ Panel A } \\
\hline SR & Coefficient & Standard error & $t$ & $p$-value \\
\hline EPS & 1.05451 & 0.3687473 & 2.86 & $0.004^{\star \star \star}$ \\
\hline BVPS & -0.0330044 & 0.0447241 & -0.74 & 0.461 \\
\hline BTC & -18.49922 & 5.135885 & -3.60 & 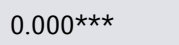 \\
\hline Intercept & 83.59319 & 22.25514 & 3.76 & $0.000 * \star *$ \\
\hline \multicolumn{5}{|c|}{ Panel B } \\
\hline $\mathbf{R}^{2}$ & 0.0676 & \multirow{2}{*}{\multicolumn{2}{|c|}{$\begin{array}{l}\text { Number of observations } \\
\text { p-value (F) }\end{array}$}} & 356 \\
\hline $\mathbf{F}$ & 9.12 & & & $0.0000 * \star \star$ \\
\hline
\end{tabular}

Note: ${ }^{*}$ means a confidence level of $90 \%$; ${ }^{\star *}$ means a confidence level of $95 \%$; ${ }^{\star \star \star}$ means a confidence level of $99 \%$.

Table 7 indicates the significance of the model as a whole, given a p value $(F)$ of 0.0000 and a general explanation power of approximately $7 \%$.

Just as in Equation (1), only EPS was significant among the control variables. Its signal remains positive and, as it was done in previous estimation, it was regressed the same parameters excluding BTC stimulus variable. In this case, specifically, the BVPS variable remains statistically insignificant; however, there is a worsening in the coefficient of EPS nearly to 0.3 units. This indicates, once again, the possible reduction of the relevance of accounting information when viewed in conjunction with external information as in the quotation of Bitcoin.

Also similar to the result in Equation (1), the result of BTC variable in Equation (2) indicates a reduction of approximately 18 units in stock returns of the companies $[\mathrm{B}]^{3}$ for each additional unit on the BTC variable. Following the same reasoning in the previous case, these results corroborate the findings from Costal and Meira (2017) and Gomes and Laporta (2018). And as a result, we could not refute the H2 proposed in this research.

Both results of equations (1) and (2) indicate, considering the data of the present research, that Bitcoin, when rising, tends to deteriorate the market value of available assets in $[\mathrm{B}]^{3}$. Considering this issue, accounting information would become less useful to external users, as advocated by Watts and Zimmerman (1990), given that Brazil's capital market would be down.

Thus, given a reduced usefulness of accounting information on predicting stock prices (or returns) and / or their utility for fewer users, the relevance of accounting information could be in check. This is even more evident when, in Equation (1), the BVPS variable presents statistical significance in the original model by Collins et al. (1997), but loses their significance when Bitcoin quotation is added to the model, and, in Equation (2), when the EPS variable has their slope reduced after the inclusion of BTC variable.

\section{FINAL CONSIDERATIONS}

Studies about the relevance of accounting information on capital market, which is called value relevance, have been exploited in the academy since the 60s, including Beaver (1968) and Ball and Brown (1968).

With the advancement of science and the need for new understandings, this field of research began to check various information prepared by accounting and, along with it, other non-accounting information began to be added together in order to understand the data rate intrinsic and extrinsic the market.

The explosion of a new market investment, the cryptocurrency one, seems to be endangering to the traditional capital markets. Considering this fact, the relevance of accounting information has been verified next to the price of Bitcoin, the most famous cryptocurrency, in 2018, for companies of $[\mathrm{B}]^{3}$.

Using the classical model of Ohlson (1995) and Collins et al. (1997), it was possible to identify the negative reaction of the stock price and the stock returns of companies listed on $[\mathrm{B}]^{3}$ due to the increase of the price of Bitcoin in the related period. This result suggests an investment preference slope in the cryptocurrency market at the expense of the capital market when the first one is on the rise. This empirical result seems to agree with some theoretical supports previously presented.

Moreover, with regard to two of the main financial statements - net income and equity - was checked a loss (or reduction) of its predictive power over the stock price and stock returns when was added the information about the price of Bitcoin. This result suggests a potential risk to the accounting science to value relevance research while the cryptocurrency market seems to be booming, something similar to what was pointed out by Bouri et al. (2017).

This research, as well as any other, has limitations. Among the main ones can be highlighted: (a) observation of only one year (2018); although the reason for this was explicated, it is possible that larger ranges may result in different findings; (b) there is a risk of endogeneity in the model by omission of important variables, however, because this is an 
initial study in this sense, there were no previous proxies to be used; and (c) the use of the quotation of only one cryptocurrency, although it is the main one. Perhaps the use of other cryptocurrency offers different results.

So, as future research suggestions, it is stated: (I) analysis of a wider chronological range, but trying if possible to keep the panel data for the control of fixed effects that would become a risk in the research; (II) include new information (accounting and non-accounting) in models formulated in this research to correct any endogeneity problems; and (III) the use of other cryptocurrency, alone or together with Bitcoin, to understand if the relationship here observed is a unique phenomenon for this cryptocurrency or is something that can be generalized to all others virtual coins.

\section{REFERENCES}

Albuquerque, B. S. D., \& Callado, M. D. C. (2015). Understanding Bitcoins: facts and questions. Revista Brasileira de Economia, 69(1), 3-16.

Alves, A., Silva, T., Macedo, M., \& Marques, J. A. (2011). A relevância dos gastos com P\&D para o mercado brasileiro de capitais: um estudo com distribuidoras de energia elétrica no período de 2002-2009. INMR - Innovation \& Management Review, 8(2), $216-239$. Retrieved from http://www.revistas.usp.br/rai/article/view/79220

Ball, R., \& Brown, P. (1968). An empirical evaluation of accounting income numbers. Journal of accounting research, 159-178.

Barth, M. E., Beaver, W. H., \& Landsman, W. R. (2001). The relevance of the value relevance literature for financial accounting standard setting: another view. Journal of accounting and economics, 31(1-3), 77-104.

Batista, A. R. A., Maia, U., \& Romero, A. (2018). Stock market under the 2016 Brazilian presidential impeachment: a test in the semi-strong form of the efficient market hypothesis. Revista Contabilidade \& Finanças, 29(78), 405-417.

Beaver, W. H. (1968). The information content of annual earnings announcements. Journal of accounting research, 67-92.

Bergstresser, D., \& Philippon, T. (2006). CEO incentives and earnings management. Journal of financial economics, 80(3), 511-529.

Bouri, E., Gupta, R., Tiwari, A. K., \& Roubaud, D. (2017). Does Bitcoin hedge global uncertainty? Evidence from wavelet-based quantile-in-quantile regressions. Finance Research Letters, 23, 87-95.

Boya, C. M. (2019). From efficient markets to adaptive markets: evidence from the French stock exchange. Research in International Business and Finance. 40, 156-165.

Chamisa, E., Mangena, M., Pamburai, H. H., \& Tauringana, V. (2018). Financial reporting in hyperinflationary economies and the value relevance of accounting amounts: hard evidence from Zimbabwe. Review of Accounting Studies, 23(4), 1241-1273.

Collins, D. W., Maydew, E. L., \& Weiss, I. S. (1997). Changes in the value-relevance of earnings and book values over the past forty years. Journal of accounting and economics, 24(1), 39-67.

Conceptual Framework for Financial Reporting. (2010). Retrieved from http://www.ifrs.org/News/Press-Releases/Documents/ ConceptualFW2010vb.pdf

Corbet, S., Lucey, B., \& Yarovaya, L. (2018). Date stamping the Bitcoin and Ethereum bubbles. Finance Research Letters, 26, 81-88.

Corrar, L., Paulo, E., \& Dias Filho, J. M. (2007). Análise multivariada para os cursos de administração, ciências contábeis e economia. São Paulo: Atlas.

Costal, G. Z. \& Meira, L. A. (2019). Criptomoedas: moedas, ativo financeiro ou uma nova tulipa? Economic Analysis of Law Review, 8(2), 482-516.

Dichev, I. D., \& Skinner, D. J. (2002). Large-sample evidence on the debt covenant hypothesis. Journal of accounting research, 40(4), 1091-1123.

Dyhrberg, A. H. (2015). Hedging capabilities of bitcoin. Is it the virtual gold? Finance Research Letters, 16, 139-144.

Drukker, D. M. (2003). Testing for serial correlation in linear panel-data models. The Stata Journal, 3(2), 168- 177.

Easley, D., O'Hara, M., \& Basu, S. (2019). From mining to markets: The evolution of bitcoin transaction fees. Journal of Financial Economics. Recuperado de http://dx.doi.org/10.2139/ssrn.3055380

Fama, E. (1970). Efficient capital markets: A review of theory and empirical work. The Journal of Finance, 25(2), 383-417.

Fonseca, R., Marques, J. A. V. C., \& Santos, O. M. (2018). Relevância da informação contábil: estudo de eventos no setor de petróleo e gás. Revista Universo Contábil, 14(3), 46-65.

Gandal, N., Hamrick, J. T., Moore, T., \& Oberman, T. (2018). Price manipulation in the Bitcoin ecosystem. Journal of Monetary Economics, 95, 86-96.

Gomes, H. S., \& Laporta T. (2018). Bitcoin já tem mais que o dobro de investidores da bolsa no Brasil. Recuperado de https://g1.globo.com/economia/educacao-financeira/noticia/bitcoin-ja-tem-mais-que-o-dobro-de-investidores-da-bolsa-no-brasil.ghtml

Grignon, P. (2009). Digital coin in brief. Retrieved from https://archive.org/details/Digital_Coin_in_Brief_07-17-09.

Gujarati, D. N., \& Porter, D. C. (2011). Basic econometrics. Boston, Mass: McGraw-Hill.

Hagerman, R. L., \& Zmijewski, M. E. (1979). Some economic determinants of accounting policy choice. Journal of accounting and economics, 1(2), 141-161. 
Hayes, A. S. (2019). Bitcoin price and its marginal cost of production: support for a fundamental value. Applied Economics Letters, 26(7), 554-560.

Healy, P. M. (1985). The effect of bonus schemes on accounting decisions. Journal of accounting and economics, 7(1-3), 85-107.

Henriques, I., \& Sadorsky, P. (2018). Can Bitcoin Replace Gold in an Investment Portfolio? Journal of Risk and Financial Management, 11(3), 1-28. 281-312

Hoechle, D. (2007). Robust Standard Errors for Panel Regressions with Cross-Sectional Dependence. The Stata Journal, 7(3),

Hur, Y., Jeon, S., \& Yoo, B. (2015). Is Bitcoin a Viable E-Business? Empirical Analysis of the Digital Currency's Speculative Nature. In: 36th International Conference on Information Systems, Fort Worth, Texas.

Laurent, L. (2018). Bitcoin's Crash Looks Like a Real Currency Crisis. Retrieved from https://www.bloomberg.com/opinion/articles/2018-11-27/bitcoin-crash-is-a-real-currency-crisis

Lopes, A. B. (2001). A relevância da informação contábil para o mercado de capitais: o modelo de Ohlson aplicado a Bovespa. (Tese de Doutorado). Universidade de São Paulo, São Paulo.

Magalhães-Timotio, J. G., Leite Filho, G. A., \& Eça, J. P. A. (2017). Investigação da ocorrência de anomalias de calendário nos índices da BM\&FBOVESPA. Revista de Gestão, Finanças e Contabilidade, 7(3), 264-278.

Marçal, R. R., Batista, T. C., \& Macedo, M. A. S. (2018). Relevância da informação contábil no mercado de capitais brasileiro: uma perspectiva por meio da análise fundamentalista em empresas do índice IBrX-50. In: XIV Congresso Nacional de Excelência em Gestão, Rio de Janeiro, RJ.

Martins, G. D. A., \& Theóphilo, C. R. (2009). Metodologia da investigação cientifica. São Paulo: Atlas.

Ohlson, J. A. (1995). Earnings, book values, and dividends in equity valuation. Contemporary accounting research, 11(2), 661-687.

Queiroz, J. M., \& de Almeida, J. E. F. (2017). Efeitos das hipóteses da teoria positiva da contabilidade na qualidade da informação contábil. Revista Universo Contábil, 13(3), 50-69.

Raiborn, C., \& Sivitanides, M. (2015). Accounting issues related to Bitcoins. Journal of Corporate Accounting \& Finance, 26(2), 25-34.

Sarlo Neto, A. (2004). A reação dos Preços das Ações à Divulgação dos Resultados Contábeis: Evidências Empíricas sobre a Capacidade Informacional da Contabilidade no Mercado Acionário Brasileiro. (Dissertação de Mestrado). Fundação Instituto Capixaba de Pesquisas em Contabilidade, Economia e Finanças - FUCAPE, Vitória, ES, Brasil.

Silva, M. Z., Mazzioni, S., \& Beuren, I. M. (2012). Análise da relação entre remuneração dos executivos e desempenho das empresas brasileiras de capital aberto. Anais... In: XIX Congresso Brasileiro de Custos, Bento Gonçalves, RS.

Song, C. J., Thomas, W. B., \& Yi, H. (2010). Value relevance of FAS No. 157 fair value hierarchy information and the impact of corporate governance mechanisms. The Accounting Review, 85(4), 1375-1410.

Sutopo, B., Kot, S., Adiati, A., \& Ardila, L. (2018). Sustainability Reporting and value relevance of financial statements. Sustainability, 10(678).

Tshipa, J., Brummer, L., Wolmarans, H., \& Du Toit, E. (2018). The impact of flexible corporate governance disclosures on value relevance. Empirical evidence from South Africa. Corporate Governance: The International Journal of Business in Society, 18(3), 369-385.

Verrecchia, R. E. (2001). Essays on disclosure. Journal of accounting and economics, 32(1-3), 97-180.

Watts, R. L., \& Zimmerman, J. L. (1978). Towards a positive theory of the determination of accounting standards. The Accounting review, 112-134.

Watts, R., \& Zimmerman, J. (1990). Positive Accounting Theory: A Ten Year Perspective. The Accounting Review, 65(1), 131-156.

Yaya, O. S., Ogbonna, E. A., \& Mudida, R. (2019). Market Efficiency and Volatility Persistence of Cryptocurrency during Pre-and Post-Crash Periods of Bitcoin: Evidence based on Fractional Integration. Munich Personal Repec Archive, 91450, 1-28. 